\title{
IMPLEMENTASI MODEL KOMUNIKASI KELOMPOK FASILITATOR DALAM PELAKSANAAN PROGRAM Rutilahu DI KOTA CIMAHI
}

\author{
Iwan Koswara dan Slamet Mulyana \\ Universitas Padjadjaran
}

\begin{abstract}
ABSTRAK
Penduduk Provinsi Jawa Barat berdasarkan Sensus Penduduk Tahun 2010 berjumlah 43,7 juta jiwa, dengan pertumbuhan 1,49 persen per tahun diproyeksikan pada tahun 2030 jumlah penduduk Jawa Barat akan mencapai 60 juta jiwa, suatu jumlah yang fantastis. Ledakan penduduk seperti itu akan akan menciptakan berbagai persoalan pelik seperti krisis pangan, kemiskinan, keterbatasan lahan tempat tinggal, kerusakan lingkungan, dan tingginya angka kriminalitas. Rumah memiliki fungsi yang sangat besar bagi individu dan keluarga tidak saja mencakup aspek fisik, tetapi juga mental dan sosial. Pemerintah Jawa Barat memiliki komitmen untuk memperbaiki kondisi kesejahteraan masyarakat miskin melalui program perbaikan rumah tidak layak huni. Kebutuhan perbaikan rumah tidak layak huni di wilayah perkotaan Provinsi Jawa Barat (9 Kota) sampai pada tahun 2014 sebanyak 17.511 unit yang tersebar di 378 kelurahan. Penelitian ini berusaha untuk melihat sejauhmana pengembangan model komunikasi kelompok Fasilitator Kelurahan terhadap upaya mensukseskan program Perbaikan Rumah Tidak Layak Huni (Rutilahu) di 3 kecamatan di Kota Cimahi Provinsi Jawa Barat. Adapun tujuan dari penelitian ini adalah untuk mengembangkan model komunikasi kelompok Fasilitator Kelurahan Badan Keswadayaan Masyarakat dalam menjalankan tugasnya mensukseskan Program Perbaikan Rutilahu di Kota Cimahi Provinsi Jawa Barat. Penelitian ini menggunakan metode kualitatif. Analisis penelitian yang digunakan adalah studi kasus berdasarkan metode, data, dan triangulasi sumber. Dalam penelitian ini akan digali hal-hal yang berkenaan dengan model komunikasi Fasilitator Kelurahan dan perannya dalam meyukseskan program Perbaikan Rutilahu di Kota Cimahi Provinsi Jawa Barat. Hasil Penelitian menunjukkan bahwa aplikasi model komunikasi fasilitator Badan Keswadayaan Masyarakat, sangat menunjang dan mendukung terhadap kelancaran kegiatan masyarakat untuk terlibat dalam mewujudkan keberhasilan program perbaikan Rutilahu.
\end{abstract}

Kata-kata Kunci: Model komunikasi kelompok, fasilitator kelurahan badan keswadayaan masyarakat, rumah tidak layak huni, Kota Cimahi, Provinsi Jawa Barat

\section{IMPLEMENTATION OF FACILITATOR GROUP COMMUNICATION MODEL IN Rutilahu IMPLEMENTATION PROGRAM IN CIMAHI}

\begin{abstract}
The residents of West Java Province based on the Population Census of 2010 amounted to 43.7 million, with a The residents of West Java Province based on the Population Census of 2010 amounted to 43.7 million, with a growth of 1.49 percent per year projected by 2030 the population of West Java will reach 60 million, an amount that was fantastic. Population explosion like that would be created various complicated problems such as the food crisis, poverty, limited residential land, environmental damage, and high crime rate. The house has a very large function for individuals and families not only include the physical aspect, but also mental and social aspects. West Java Government is committed to improve the welfare conditions of the poor through improvement program uninhabitable houses. Needs improvement uninhabitable houses in urban areas of West Java Province (9 Cities) until the year 2014 as many as 17511 units spread across 378 villages. This study sought to examine the extent of the development model of group communication facilitators to efforts to make the program successful Village Home Improvement Not Livable in 3 districts in Cimahi, West Java Province. The purpose of this study was to develop a model of group communication facilitator Village Community Self-Reliance Agency in carrying out its duties succeed the Home Improvement Program Not Livable in Cimahi, West Java Province. This study uses a qualitative method. The analysis of the research is based on the case study method, data, and triangulation of sources. In this research, it will be explored things related to model village facilitators of communication and its role in program to succeed the improvement of Not Livable House programs in Cimahi, West Java Province.
\end{abstract}

Keywords: Model of communications group, the facilitators of village community self-reliance agency, not livable house, Cimahi, West Java Province

Korespondensi: Dr. Iwan Koswara, M.Si. Program Studi Manajemen Komunikasi, Fakultas Ilmu Komunikasi Universitas Padjadjaran, Jln. Raya Jatinangor Km.21.Email: iwankoswara17@gmail.com 


\section{PENDAHULUAN}

Krisis ekonomi yang melanda bangsa Indonesia sejak tahun 1997 dan sampai saat ini belum sepenuhnya pulih menyisakan persoalan kemiskinan yang berat bagi masyarakat, tak terkecuali di Jawa Barat. Sungguhpun berbagai upaya pemulihan telah dilakukan baik oleh pemerintah, masyarakat, swasta dan lainnya, namun persoalan kemiskinan dalam berbagai dimensi kehidupan masih memperlihatkan wajah yang menyedihkan. Di berbagai tempat kita masih menyaksikan berbagai kesulitan hidup mendera masyarakat, baik secara ekonomi, sosial, lingkungan, pendidikan, kesehatan dan lain sebagainya.

Undang-Undang No. 1 Tahun 2011 tentang Perumahan dan Kawasan Permukiman, bahwa setiap orang berhak hidup sejahtera lahir dan batin, bertempat tinggal dan mendapatkan lingkungan hidup yang baik dan sehat. Rumah memiliki fungsi yang sangat besar bagi individu dan keluarga tidak saja mencakup aspek fisik, tetapi juga mental dan sosial.

Gubernur Ahmad Heryawan melalui kepemimpinan Pemerintah Jawa Barat memiliki komitmen kuat untuk memperbaiki kondisi kesejahteraan masyarakat miskin melalui program perbaikan rumah tidak layak huni. Kebutuhan perbaikan rumah tidak layak huni di wilayah perkotaan Provinsi Jawa Barat (9 Kota) merujuk hasil survei dan pemetaan PNPM Mandiri Perkotaan sampai pada tahun 2014 sebanyak 17.511 unit yang tersebar di 378 kelurahan. Pada tahun 2015 direncanakan pelaksanaan peningkatan kualitas rumah tidak layak huni perkotaan sebanyak 3.000 unit sebesar Rp. 45.000.000.000,-

Menyadari pentingnya kebutuhan dari masyarakat terhadap sarana rumah yang sehat, aman dan nyaman (layak huni), maka Pemerintah Provinsi Jawa Barat berkomitmen untuk memberikan stimulan bagi tersedia nya rumah yang layak huni. Rumah yang sehat, aman dan nyaman diyakini mampu memberikan motivasi dan kesehatan yang lebih baik bagi penghuninya, dengan sendirinya dapat memacu produktifitas.

Komunikasi memiliki peran penting dalam setiap tindakan yang bertujuan untuk memotivasi kelompok. Sulit untuk membayangkan bagaimana sebuah pesan dapat disampaikan untuk peningkatan kesejahteraan anggota kelompok jika kita tidak bisa berkomunikasi. Menurut Poole (1999: 5) Proses komunikasi adalah transaksi multi-dimensi yang dipengaruhi oleh berbagai faktor. Dalam komunikasi kelompok keberhasilan pertukaran informasi antara mentor dan target audiens merupakan aspek yang telah mendapat perhatian utama.

Komunikasi dalam kelompok dapat didefinisikan dalam banyak cara yang sama seperti komunikasi secara umum yaitu adanya proses transaksional. Perbedaan utama dalam komunikasi kelompok adalah bahwa fokusnya adalahkhususuntukinformasi yang berguna bagi anggota kelompok. Penambahan 'kelompok' dengan definisi komunikasi sebagai 'sumber' yang memungkinkan tersampaikannya pesan di dalam kelompok (misalnya kekompakan, saling membantu diantara anggota kelompok) digunakan dalam kerjasama kelompok dan mencegah terjadinya perpecahan. (Boton dan Kreps: 2000)

Penelitian ini berusaha untuk melihat sejauhmana pengembangan model komunikasi kelompok Fasilitator Kelurahan terhadap upaya mensukseskan program Perbaikan Rumah Tidak Layak Huni di tiga kecamatan di Kota Cimahi Provinsi Jawa Barat. Adapun tujuan dari penelitian ini adalah untuk mengembangkan model komunikasi kelompok Fasilitator Kelurahan Badan Keswadayaan Masyarakat dalam menjalankan tugasnya menyukseskan Program Perbaikan Rumah Tidak Layak Huni di Kota Cimahi Provinsi Jawa Barat.

\section{METODE PENELITIAN}

Penelitian ini menggunakan metode kualitatif. Analisis penelitian yang digunakan adalah studi kasus berdasarkan metode, data, dan triangulasi sumber. Berdasarkan sifat data ini, masalah penelitian dapat dipahami setelah melakukan konfirmasi data kualitatif yang diperoleh dari deskripsi hasil wawancara dengan informan.

Nara sumber yang dijadikan informan dalam penelitian ini dipilih berdasarkan kriteria (1) Subjek penelitian bersedia menerima kehadiran peneliti, (2) Berkemampuan dan berkemauan untuk mengutarakan pengalaman- 
pengalaman masa lalu dan masa sekarang, (3) memahami seluk beluk permasalahan, serta memiliki pengalaman menarik dalam penanganan kasus yang menjadi kajian penelitian ini.

Teknik pengumpulan data yang dilakukan dalam penelitian iniadalahobservasi, wawancara mendalam (depth interview), dan studi literatur (kepustakaan). Observasi dilakukan dengan mengamati langsung aktivitas yang dilakukan masyarakat pada saat kegiatan berlangsung, Wawancara mendalam dengan informan yang relevan dengan masalah yang diteliti, dan studi literatur berupa penelusuran atau pencarian informasi yang berkaitan dengan masalah yang relevan dengan penelitian ini.

Dalam penelitian ini akan digali hal-hal yang berkenaan dengan model komunikasi Kelompok Fasilitator Kelurahan Badan Keswadayaan Masyarakat Dalam Program Perbaikan Rumah Tidak Layak Huni di Kota Cimahi Provinsi Jawa Barat.

\section{HASIL DAN PEMBAHASAN}

Penelitian lapangan dilakukan di 3 (tiga) lokasi kecamatan di Kota Cimahi, yaitu Kecamatan Cimahi Selatan, Cimahi Tengah, dan CimahiUtara. Disetiap Kecamatan yangmenjadi lokasi penelitian, peneliti melakukan wawancara dengan anggota masyarakat, serta beberapa tokoh yang terkait dengan permasalahan yang diteliti diantaranya Ketua Fasilitator Kecamatan, Ketua Badan Keswadayaan Masyarakat, Aparat pemerintahan, Camat dan atau yang mewakili, serta Kepala Bidang Pemukiman dan Perumahan Dinas Pekerjaan Umum Kota Cimahi

Kota Cimahi merupakan kota yang sangat pesat perkembangannya baik dalam aspek ekonomi, sosial maupun budaya, dan sekaligus juga memiliki beberapa permasalahan dalam perkembangan pembangunan sarana prasarana maupun Sumber Daya Manusianya.

Satu aspek penting temuan lapangan ini yang terkait dengan permasalahan yang dihadapi jajaran pemerintahan kota Cimahi, juga sejalan dengan program yang dicanangkan Pemerintah Provinsi Jawa Barat adalah masalah Permukiman, yang dalam hal ini adalah program mengenai perbaikan rumah tidak layak huni. Program ini berlangsung tentu tidak lepas dari berbagai aspek yang terkait didalamnya selain pesatnya pertumbuhan penduduk, lemahnya kemampuan masyarakat dalam aspek ekonomi juga ditunjang oleh kondisi atau letak Geografis Kota Cimahi. Cimahi menyandang peran sebagai daerah penyangga bagi Kota Bandung yang berjarak sekitar $12 \mathrm{~km}$ di sebelah barat. Kota Cimahi terdiri dari 3 kecamatan yaitu Kecamatan Cimahi Utara, Cimahi Tengah, dan Cimahi Selatan seluas 40,25 $\mathrm{km}^{2}$ dengan jumlah penduduk keseluruhan sejumlah 452.390 jiwa, dari 15 kelurahan, kondisi ini tergolong padat, yang tentunya berpengaruh terhadap aspek sosial ekonomi kehidupan masyarakatnya.

Berdasarkan berbagai kondisi yang ada tersebut, Pihak pemerintahan Kota Cimahi melakukan berbagai upaya untuk mensejahterakan kehidupan masyarakatnya, diantaranya adalah mencanangkan program bantuan dan perbaikan rumah tidak layak huni (Rutilahu). Hal ini sejalan dengan apa yang telah direncanakan dan ditargetkan oleh Pemerintah Provinsi Jawa Barat.

Berkenaan dengan perencanaan program tersebut, Pemerintah Kota Cimahi diwakili oleh Bidang Pemukiman dan Perumahan Dinas Pekerjaan Umum merupakan pelaksana teknis Program Perbaikan Rumah Tidak Layak Huni (Rutilahu) yang telah dicanangkan Pemerintah Provinsi Jawa Barat. Sejalan dengan kegiatan ini, maka Pemerintah Kota Cimahi melakukan koordinasi dengan para Fasilitator Badan Keswadayaan Masyarakat (BKM) di Kecamatan Cimahi Selatan, Kecamatan Cimahi Tengah, dan Kecamatan Cimahi Utara dimana keberadaan mereka merupakan ujung tombak pelaksanaan program Rutilahu di wilayahnya.

Berkaitan dengan temuan hasil lapangan, maka ada beberapa langkah penting dalam pelaksanaan mengenai program perumukiman ini yaitu; (1) Badan Keswadayaan Masyarakat (BKM)menyerahkanproposaluntukdiverifikasi, (2) Kelurahan lalu memverifikasi, mencatat dan mengirim hasilnya ke Fasilitator kelurahan, (3) Fasilitator kelurahan menerima hasil verifikasi BKM, meninjau langsung kelapangan dan memeriksa kelengkapan administrasi kemudian dikirim ke kordinator kota, (4) Kordinator kota mengevaluasi dan selanjutnya diserahkan kepada Pemerintah Kota, (5) Pemerintah Kota menyiapkan Surat Rekomendasi kepada Kepala Dinas, (6) Konsultan Provinsi menyiapkan Surat 
Rekomendasi kepada Pemerintah Provinsi, dan (7) Pemerintah Provinsi mengevaluasi, memverifikasi dan memproses permohonan yang diajukan.

Rangkaian tahapan kegiatan ini apabila digambarkan, tampak seperti Gambar 1 .

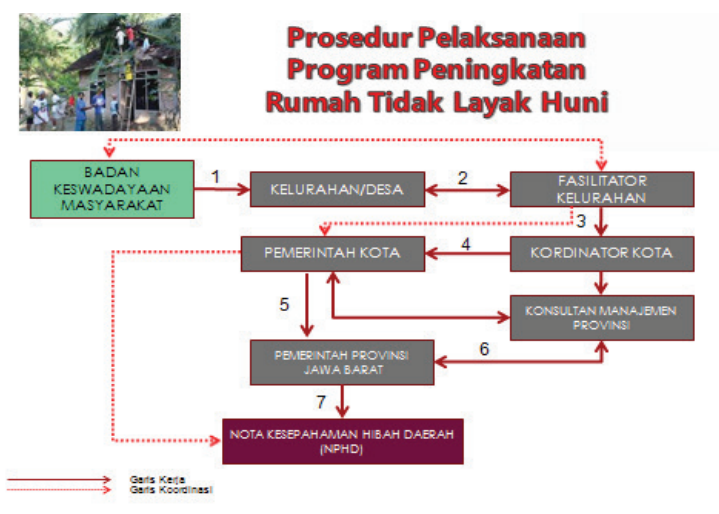

\section{Gambar 1 Prosedur Pelaksanaan Program RUTILAHU}

Program Perbaikan Rumah Tidak Layak Huni (Rutilahu) Pemerintah Provinsi Jawa Barat telah menetapkan misi: membangun masyarakat mandiri yang mampu menjalin kebersamaan dan sinergi dengan pemerintah maupun kelompok peduli setempat dalam menanggulangi kemiskinan secara efektif dalam tatanan good governance, serta mampu mewujudkan terciptanya lingkungan permukiman yang tertata, sehat, produktif dan berkelanjutan (neighbourhood development).

Untuk dapat mencapai misi tersebut tentu membutuhkan kerja keras dari semua pihak dan dilakukan secara terus menerus dalam melakukan proses pemberdayaan masyarakat. Untuk mampu menggemban misi tersebut maka dibutuhkankualitassumberdayamanusiadengan kualitas yang memadai dari sisi pengetahuan, keterampilan, maupun pengalamannya dalam mendampingi masyarakat, sehingga seluruh fasilitator kelurahan yang ada di lapangan wajib memahami secara utuh konsep dasar Program Perbaikan Rumah Tidak Layak Huni di Provinsi Jawa Barat. Adapun Teknis pelaksanan program perbaikan rumah tidak layak huni adalah: (1) Pelaksanaan program Rutilahu dilakukan oleh masyarakat secara swakelola berdasarkan prinsip otonomi dan difasilitasi oleh perangkat pemerintahan dengan dibantu oleh fasilitator, (2) Pelaksanaan kegiatan meliputi pemilihan dan penetapan anggota Badan Keswadyaan Masyarakat (BKM), penyusunan proposal dan pencairan dana hibah, pengerahan tenaga kerja, pengadaan barang, serta pelaksanaan kegiatan yang diusulkan, (3) Struktur organisasi BKM ditetapkan oleh anggota, bertanggung jawab dalam realisasi fisik, keuangan, serta administrasi kegiatan/pekerjaan yang dilakukan sesuai rencana swakelola, (4) Dalam proses pengadaan barang dan jasa yang dilakukan harus diperhatikan prinsip-prinsip efisien, efektif, terbuka, adil dan bertanggung jawab.

Seiring dengan dinamika di lapangan serta sering keluar masuknya para fasilitator kelurahan dan reorganisasi dalam pelaksanaan Program Perbaikan Rumah Tidak Layak Huni ditemukan pula beberapa masalah atau hambatan, diantaranya: (1) Adanya fasilitator kelurahan yang masih belum memahami tugas dan fungsinya sebagai ujung tombak kesuksesan pelaksanaan program Perbaikan Rumah Tidak Layak Huni ini, (2) Dalam praktik lapangan sering kali terkendala dengan mandegnya dan atau tidak lancarnya arus pesan yang berlangsung serta terjadinya kesalah pemahaman terhadap apa yang menjadi permasalahan yang dihadapi, (3) Ketidak tepatan waktu dalam pelaksanaan kegiatan, (4) Waktu pertemuan antara fasilitator kelurahan, dengan Badan Keswadyaan Masyarakat, serta masyarakat penerima program Rutilahu, dan (5) Terkadang terjadi aspek lain yaitu adanya keterlambatan sarana/prasarana atau material bagi pelaksnaan program Rutilahu tersebut.

Mengacu terhadap apa yang terjadi di lapangan mengenai bagaimana implementasi model komunikasi kelompok fasilitator kelurahan dalam pelaksanaan program Rutilahu ini, maka beberapa langkah antisipasi untuk lancarnya pelaksanaan program ini, dilakukan dengan strategi pengembangan kapasitas yang secara rutin melalui pelatihan dasar fasilitator kelurahan program Rutilahu. Strategi ini dirasakan sangat tepat karena peran fasilitator kelurahan yang sangat penting karena secara langsung memfasilitasi masyarakat agar mampu melakukan perubahan diri, perubahan sosial melalui proses pemberdayaan masyarakat.

Pelatihan Dasar bagi Fasilitator Kelurahan dititikberatkan sebagai proses penyadaran (awareness training) dengan penekanan pada: (1) Re-orientasi sikap dan pola pikir dan pandangan dalam pembangunan, utamanya penanggulangankemiskinandiperkotaanmelalui pembangunan manusia (pemulihan nilai-nilai 
luhur), (2) Pengenalan dan pemahaman konsep Program Rutilahu dan mekanisme kerjanya, (3) Pengenalan dan pemahaman dasar-dasar pembangunan yang melibatkan masyarakat sasaran sebagai pelaku utama (subjek) melalui proses pemberdayaan, (4) Pengenalan dan pemahaman mengenai partisipasi perempuan, (5) Pengenalan dan pemahaman mengenai IPM dan MDGs yang menjadi kerangka kebijakan penanggulangan kemiskinan tingkat nasional. Selain hal tersebut juga diberikan materi tentang pengenalan dan pemahaman tentang konsep dan indikator masyarakat mandiri. Kemudian pada tatanan praktis, bagaimana fasilitator melakukan fasilitasi terhadap kelompok Badan Pemberdayaan Masyarakat yang menjadi dampingannya.

Berdasarkan peran yang dilakukannya maka tugas-tugas Fasilitator Kelurahan Badan Keswadayaan Masyarakat Program Rutilahu adalah sebagai berikut: (1) Memfasilitasi Badan Keswadayaan Masyarakat (BKM) dalam menetapkan penempatan lokasi Rutilahu sebagaimana ketentuan, (2) Memfasilitasi BKM dalam menyusun Proposal Pencairan Bantuan Program Rutilahu, (3) Memfasilitasi BKM dalam mendorong, menggerakan partisipasi dan swadaya masyarakat, (4) Memfasilitasi dan mensupervisi BKM dalam pelaksanaan perbaikan Rutilahu, (5) Memfasilitasi BKM dalam menyusun laporan pertanggung jawaban penggunaan dana selambat-lambatnya 2 (dua) minggu setelah pekerjaan selesai.

Terkait dengan apa yang menjadi tugas fasilitator BKM, maka jalinan komunikasi yang baik, yang secara kontinu, merupakan pola komunikasi yang harus dikembangkan, sehingga terjadi pemahaman dan keterbukaan terhadap apa yang menjadi harapan dari target pelaksananaan program Rutilahu ini.

Dengan demikian kesinergian koordinasi tim kelompok fasilitator kelurahan dengan Badan Keswadayaan Masyarakat merupakan hal yang sangat penting, dimana keberadannya dapat menjadi pendorong terhadap kesuksesan pelaksanaaan program Rutilahu, oleh karena itu proses komunikasi yang terjalin antara fasilitator, BKM, serta masyarakat merupakan faktor penting dalam pengembangan dan pelaksanaan program tersebut, sehingga dapat terbentuk pola komunikasi.

Komunikasi memegang peranan penting dalam kehidupan manusia, tanpa komunikasi kehidupan manusia tidak akan bermakna, atau bahkan tidak bisa bertahan hidup. Komunikasi merupakan proses penyampaian informasi dari seorang kepada orang lainnya, atau dari seseorang kepada kelompoknya.

Komunikasikelompokadalahkomunikasi yang berlangsung antara beberapa orang dalam suatu kelompok "kecil" seperti dalam rapat, pertemuan, konferensi dan sebagainya (Arifin, 1984), sedangkan Michael Burgoon (dalam Wiryanto, 2005) mendefinisikan komunikasi kelompok sebagai interaksi secara tatap muka antara tiga orang atau lebih dengan tujuan yang telah diketahui, seperti berbagi informasi, menjaga diri, pemecahan masalah, yang mana anggota-anggotanya mengingat karakteristik pribadi anggota-anggota yang lain secara tepat. Kedua definisi komunikasi kelompok di atas mempunyai kesamaan, yakni adanya komunikasi tatap muka, dan memiliki susunan rencana kerja tertentu umtuk mencapai tujuan kelompok.

Kelompok adalah sekumpulan orang yang mempunyai tujuan bersama yang berinteraksi satu sama lain untuk mencapai tujuan bersama, mengenal satu sama lainnya, dan memandang mereka sebagai bagian dari kelompok tersebut (Mulyana, 2005). Kelompok ini misalnya adalah keluarga, kelompok diskusi, kelompok pemecahan masalah, atau suatu komite yang tengah berapat untuk mengambil keputusan. Dalam komunikasi kelompok, juga melibatkan komunikasi antarpribadi. Karena itu kebanyakan teori komunikasi antarpribadi berlaku juga bagi komunikasi kelompok.

Newcomb (1930) melahirkan istilah kelompok keanggotaan (membership group) dan kelompok rujukan (reference group). Kelompok keanggotaan adalah kelompok yang anggota-anggotanya secara administratif dan fisik menjadi anggota kelompok itu. Sedangkan kelompok rujukan adalah kelompok yang digunakan sebagai alat ukur (standard) untuk menilai diri sendiri atau untuk membentuk sikap.

Aspek penting dalam kelompok adalah adanya konformitas. Konformitas merupakan perubahan perilaku atau kepercayaan menuju (norma) kelompok sebagai akibat tekanan kelompok yang real atau dibayangkan. Bila sejumlah orang dalam kelompok mengatakan 
atau melakukan sesuatu, adakecenderungan para anggota untuk mengatakan dan melakukan hal yang sama. Jadi, kalau anda merencanakan untuk menjadi ketua kelompok,aturlah rekan-rekan anda untuk menyebar dalam kelompok. Ketika anda meminta persetujuan anggota, usahakan rekan-rekan anda secara persetujuan mereka. Tumbuhkan seakan-akan seluruh anggota kelompok sudah setuju. Besar kemungkinan anggota-anggota berikutnya untuk setuju juga. Berkaitan dengan itu pula lah maka komunikasi memiliki peran penting dalam setiap tindakan yang bertujuan untuk memotivasi kelompok. Sulit untuk membayangkan bagaimana sebuah pesan dapat disampaikan untuk peningkatan kesejahteraan anggota kelompok jika kita tidak bisa berkomunikasi.

Sejalan dengan pernyataan tersebut Robert Zajonz (1965) menjelaskan bahwa kehadiran orang lain dianggap menimbulkan efek pembangkit energi pada perilaku individu. Efek ini terjadi pada berbagai situasi sosial, bukan hanya didepan orang yang menggairahkan kita. Energi yang meningkat akan mempertingi kemungkinan dikeluarkannya respons yang dominan. Respons dominan adalah perilaku yang kita kuasai. Bila respons yang dominan itu adalah yang benar, terjadi peningkatan prestasi. Bila respons dominan itu adalah yang salah, terjadi penurunan prestasi. Untuk pekerjaan yang mudah, respons yang dominan adalah respons yang benar; karena itu, peneliti melihat kelompok dapat meningkatkan kualitas kerja individu. Salah satu aspek penting dalam mendukung kinerja dan kualitas kerja individu adalah dengan pendekatan model komunikasi kelompok, yangdalam hal inimelaluipendekatan model Three Way Fit. David Corten (1989) yang memberikan sebuah gambaran tentang model pengembangan progam melalui pendekatan dan pelaksanaan manajemen kelompok.

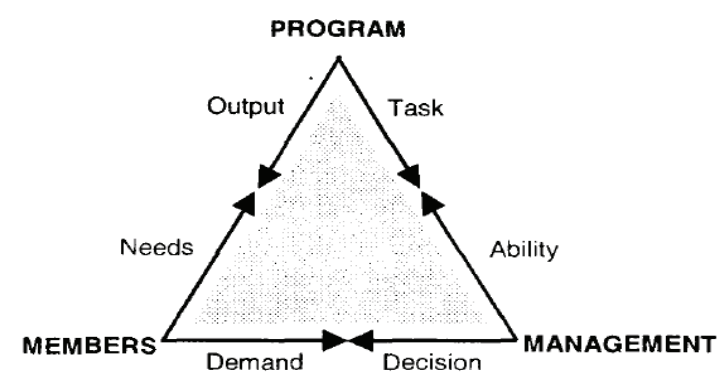

Sumber: David Corten (1989)

Gambar 2 Model Three Way Fit
Model komunikasi kelompok ini dapat digunakan untuk memandu pengembangan program kegiatan. Teori dan model komunikasi kelompok berguna dalam lingkup perencanaan, pelaksanaan dan evaluasi program kegiatan. Model komunikasi dalam kelompok fasilitator kineja, biasanya berusaha untuk memasukkan unsur-unsur kunci penting mengenai perilaku dan proses pengambilan keputusan.

Program Peningkatan Rumah Tidak Layak Huni merupakan komitmen Pemerintah Provinsi Jawa Barat untuk memberikan stimulan bagi tersedianya rumah yang layak huni. Rumah yang sehat, aman dan nyaman diyakini mampu memberikan motivasi dan kesehatan yang lebih baik bagi penghuninya, dengan sendirinya dapat memacu produktivitas. Saat ini Target program Rutilahu Perkotaan pada tahun 2015 ini adalah melakukan Peningkatan Kualitas Rumah Tidak Layak Huni sebanyak 3.000 unit rumah yang tersebar di 9 Kota di Jawa Barat. Secara Khusus untuk Kota Cimahi pada tahun 2015 ini ditargetkan terbangun 305 unit rumah yang tersebar di 3 kecamatan, yaitu Kecamatan Cimahi Selatan, Kecamatan Cimahi Tengah, dan Kecamatan Cimahi Utara dengan anggaran sebesar Rp. 4.575.000.000,-(Dinas Permukiman Cimahi 2015).

Untuk mewujudkan program Rutilahu tersebut, tentu tidak mudah. Komunikasi kelompok yang dibangun Fasilitator kelurahan dengan Badan Keswadayaan Masyarakat merupakan wujud konkrit pelaksanaan program Rutilahu. Melalui pendekatan model komunikasi kelompok yang diadopsi dari David Corten (1989), maka Pengembangan model komunikasi kelompok fasilitator kelurahan Badan Keswdayaan Masyarakat untuk mendukung pelaksanaan dari program pembangunan Rutilahu ditunjukkan oleh Gambar 3.

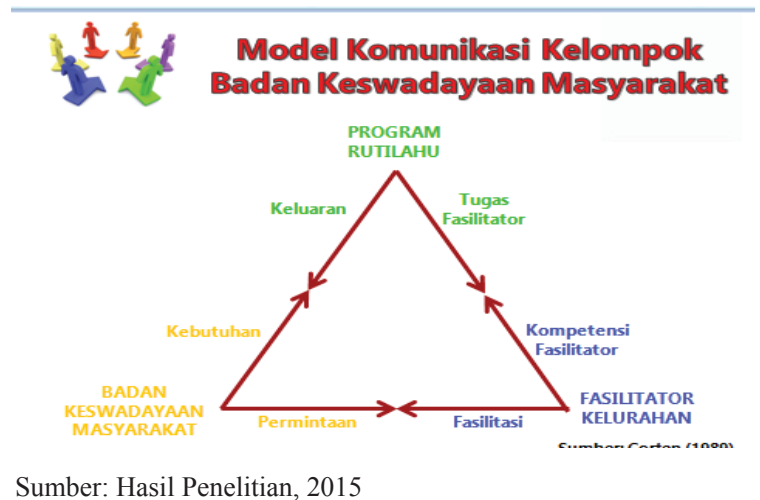

Gambar 3 Implementasi model three way fit pada Program Rutilahu 
Model Three Way Fit atau Triangle Fit of Participation dari David Corten (1989) ini menekankan pada kesesuaian diantara ketiga unsur dalam pelaksanaan program Rutilahu, yaitu Program, Fasilitator, dan Badan Keswadayaan Masyarakat (BKM). Keberhasilan pencapaian tujuan program ditentukan oleh kesesuaian yang bersifat timbal balik diantara Kebutuhan BKM dengan Keluaran atau Manfaat yang diterima dari Program Rutilahu. Demand atau Permintaan BKM dengan Fasilitasi atau Pendampingan dari Fasilitator, dan Tugas dari Program dengan Kapasitas atau Kompetensi dari Fasilitator itu sendiri.

Berdasarkan mekanisme yang dibangun bersama antara fasilitator kelurahan dengan BKM, maka dalam implementasi pelaksanaan program Rutilahu berbagai aktivitas telah dilakukan oleh tim fasilitator kelurahan dengan BKM, yaitu: Tim fasilitator bertemu secara tatap muka dengan BKM setiap 2 minggu sekali untuk membahas berbagai aspek kepentingan dalam pelaksanaan program Rutilahu, akan tetapi pada saat proses pembangunan, tim fasilitator dan BKM hampir setiap hari bertemu untuk mengontrol mekanisme proses di lapangan.

Selain itu Tim Fasilitator pun memberikan berbagai jenis pendampingan. Pendampingan yang dilakukan diantaranya adalah penyusunan dan pembuatan proposal, hingga pencairan dana hibah, pemantauan dan pelaksanaan pekerjaan Rutilahu, dan pelaporan keuangan program Rutilahu.

Fasilitator yang bekerja efektif memiliki keterampilan komunikasi interpersonal yang baik, ramah, memahami kebutuhan masyarakat, memiliki pemahaman akan budaya lokal, keterampilan dan bersikap proaktif, dan Para anggota BKM pun menyatakan kepuasannya bahwa tim fasiliator sering berkunjung ke lokasi Rutilahu memberikan bimbingan teknis dan berbagi formasi serta terus mendukung dan membantu terhadap pencapaian program Rutilahu tersebut.

Fasilitator dengan kompetensi tertentu direkrut oleh Pemerintah Provinsi Jawa Barat untuk melakukan fasilitasi atau pendampingan kepada Badan Keswadayaan Masyarakat selama proses pelaksanaan program Rutilahu berjalan. Merupakan ujung tombak yang sangat penting dalam mensukseskan pelaksanaan program Rutilahu. Oleh karena itu, pola komunikasi yang terjalin baik dan berlangsung lancar antar fasilitator kelurahan dangan Badan keswadayaan Masyarakat ini, ternyata mampu mendorong dan menggerakkan masyarakat untuk turut serta terlibat dalam pelaksnaan program perbaikan rumah tidak layak huni. Aspek lainnya ketika pesan terlambat atau tidak sampai, maka dengan mengatur waktu pertemuan antara tim fasilitator, Badan Keswadayaan Masyarakat serta masyarakat itu sendiri maka informasi tersebut dengan cepat dapat diterima.

Kesalahpemahaman, ketidakmengertian persoalan bukan merupakan persoalan tersendiri bagi fasilitator, dan Badan Keswadayaan, namun juga dipengaruhi oleh pendidikan, dan pemahamannya terhadap persoalan yang dihadapinya, selain itu berbagai aspek kendala lainnya yaitu, dalam proses pelaksanaan di lapangan ketika kegiatan perbaikan rumah tersebut dilaksanakan kadang terjadi keterlambatan pengirim bahan material, kurang baiknya kemampuan para pekerja dalam memperbaiki atau membangun rumah, ini menimbulkan kesalah pahaman diantara masyarakat dengan tim kelompok fasilitator badan keswadayaan masyarakat, seolah-olah ada perlakukan berbeda antara perbaikan terhadap satu rumah tidak layak huni dengan rumah lainnya.

Di sinilah peran fasilitator yang harus mampu mengkomunikasikan dan memberikan pengertian agar tidak terjadi kesalah pahaman tersebut. Oleh karena itu melalui pengembangan Model Three Way Fit atau Triangle Fit of Participation dari David Corten (1989), tim fasilitator kelompok dapat mengaplikasikan bagaimana perencanaan, pelaksanaan, dan evaluasi kegiatan program Rutilahu ini, dengan adanya kesesuaian, kesepahaman, dan koordinasi diantara ketiga unsur dalam pelaksanaan program Rutilahu yaitu; Program, Fasilitator, dan Badan Keswadayaan Masyarakat (BKM).

Dengan demikian proses komunikasi kelompok yang difasilitasi oleh fasilitator BKM ini merupakan jembatan yang memfasilitasi kebutuhan masyarakat terhadap program yang dicanangkan oleh pemerintah Kota Cimahi dalam melaksanakan program perbaikan rumah tidak layak huni. 


\section{SIMPULAN}

Berdasarkan hasil penelitian ini dapat diambil simpulan sebagai berikut: Model Komunikasi Kelompok Three Way Fit menuntut petugas fasilitator kelompok Badan Keswadayaan Masyarakat untuk memiliki komitmen penuh dan disiplin tinggi dalam melaksanakan tugasnya, karena tantangan dan pelaksanaannya tidak mudah. Tugas, fungsi dan peran fasilitator kelurahan sangat krusial dalam mensukseskan program Rutilahu, para Fasilitator Kelurahan dituntut memiliki kemampuan komunikasi interpersonal yang baik sehingga dapat menje-laskan berbagai persoalan yang dihadapi serta mendorong partisipatif masyarakat untuk turut aktif dalam program Rutilahu ini. Kelebihan model ini adalah cukup sederhana dan sangat dinamis karena dapat disesuaikan dengan situasi dan kondisi yang ada, Pemerintah Daerah kota Cimahi, didukung oleh fasilitator kelurahan dan Badan Keswadayaan Masyarakat, dengan keberhasilannya dalam pelaksaaan program Rutilahu ini, tentunya merupakan pilot project dari program kesejahteraan masyarakat yang dicanangkan oleh Pemeritah Provinsi Jawa Barat.

Sebagaimana yang telah dipaparkan di atas, maka ada beberapa saran yang kiranya perlu untuk disampaikan yaitu sebagai berikut: (1) Perlu adanya pemutakhiran data mengenai masyarakat yang layak mendapat bantuan program Rutilahu melalui koordinasi antara Pihak RT/RW, Kelurahan, Kecamatan termasuk dengan tim fasilitator, (2) Perlunya penambahan waktu bagi Tim Fasilitator untuk menyelesaikan tugas dan tanggung Jawabnya, (3) Perlu adanya penambahan jumlah orang/tim fasilitator, karena kompleksnya permasalahan yang dihadapi, (4) Diadakannya Peningkatan kapabilitas fasilitator melalui pelatihan teknis dan komunikasi, dan (5) Perlu adanya peningkatan dana program Rutilahu, mengingat berbagai aspek yang dihadapi seperti; kondisi alam, cuaca, harga bahan, jarak tempuh, serta sarana infrastruktur.

\section{DAFTAR PUSTAKA}

Arikunto, S. (2006). Prosedur penelitian suatu pendekatan praktik. Jakarta: Rineka Cipta.

Azwar, S. (2000). Sikap manusia: teori dan pengukurannya. Yogyakarta: Pustaka
Pelajar.

Bormann, E. (1983). Symbolic convergence: organizational communication and culture. In L. L. Putnam \& M. E. Pacanowsky (Eds.). Communication and organizations: an interpretive approach. Beverly Hills, CA: Sage.

Brown, B, Crawford, P \& Carter, R. (2006). Evidence based health communication. New York: McGraw-Hill House.

Cangara, H. (1998). Pengantar ilmu komunikasi. Jakarta: Raja Grafindo Persada.

Citrobroto, S. (1989). Prinsip-prinsip dan tehnik berkomunikasi. Jakarta: Bharata Karya Aksara.

Corten, D. (1989). People centered development: contributions toward theory and planning frameworks. Connecticut Kumarian Press.

Frey, L., Boton, C., \& Kreps, G. (2000). Investigating communication: an introduction to research methods, 2nd ed. Boston: Allyn and Bacon.

Gouran, D., \& Hirokawa, R. (1996). Functional theory and communication in decisionmaking and problem-solving groups: An expanded view. In R. Hirokawa \& $\mathrm{M}$. Poole (Eds.). Communication and group decision making, 2nd ed. Thousand Oaks, CA: Sage.

Hovland, C. I, Janis, I. L., \& Kelley, H. H. (1953). Communication and persuasion: psychological studies of opinion change. London: Yale University Press.

Infante, D. A., Rancer, A. S., \& Womack, D. F. (1990). Building communication theory. Illinois: Waveland Press, Inc.

Mueller, D. J. (1986). Mengukur Sikap-sikap sosial: buku pegangan bagi para ahli riset dan pekerja lapangan. New York: Teachers College Press.

Mulyana, D. (2001). Metodologi penelitian kualitatif: paradigma baru ilmu komunikasi dan ilmu sosial lainnya. Bandung: Remaja Rosdakarya.

Poole, M. (1999). Group Communication Theory. The handbook of group communication theory and research ed. L. Frey; D. Gouran; and M. Poole. Thousand Oaks, CA: Sage. 